\title{
AMBIENT AIR QUALITY ASSESSMENT OF JALNA CITY (MS), INDIA
}

\section{B.S. DOBHAL ${ }^{\mathrm{a}}$, R.P. SHIMPI ${ }^{\mathrm{b} 1}$ AND MAZAHAR FAROOQUI ${ }^{\mathrm{c}}$}

${ }^{\mathrm{ab}}$ State Ambient Air Quality Monitoring Programme (SAMP), Badrinarayan Barwale College, Jalna, Maharashtra India ${ }^{\mathrm{c}}$ Department of Chemistry, Dr. Rafiq Zakaria College for Women, Navkhanda, Aurangabad, Maharashtra, India

\begin{abstract}
The ambient air quality of Jalna city has been evaluated using air quality index (AQI). Air pollutants concentration$\mathrm{SO}_{2}$, NOx, RSPM and NRSPM were assessed at residential and industrial sites for one-year period. The monthly, seasonal and annual AQI values determined at both residential and industrial sites for a year. Results suggest better air quality at residential sits than industrial. Government regulations, efficient treatments in plants, proper waste disposal helped in pollution reduction. Annual mean concentrations of $\mathrm{SO}_{2}$ and $\mathrm{NOx}$ found within the permissible limits of Indian National Ambient Air Quality standards (NAAQS), while RSPM and NRSPM concentrations violated at both sites. The annual AQI values 127.79 and 88.50 were recorded for residential and industrial site respectively due to higher RSPM.
\end{abstract}

KEYWORDS: Air Quality Index (AQI), RSPM-Respirable Suspended Particulate Matter, NRSPM- Non Respirable Suspended Particulate Matter, Gaseous pollutants- $\mathrm{SO}_{2}, \mathrm{NOx}$

Environmental pollution is increasing at alarming rate as shown by monitoring agencies and climate change. Over population, scarce public facilities (Tashiro and Taniyama, 2002), urbanization (Atash, 2007), automobile emissions (Baladauf et al., 2009) and industrialization (Harison and Yin, 2000) (Kim et al., 2002) (Sharek et al., 2007) detoriates the climate. Human health, assets and environment (Hrdlickova et al., 2008) (Gupta et al., 2003) (Celis et al., 2004) (Zhang et al., 2007) are spoiled by these factors. Sulphur dioxide, nitrogen oxides and particulate matter are key pollutants indicated by environment protection agency. Factors like pollution sources-local and distant, meteorological and topographical conditions, variations-spatial and temporal (Franchini and Mannucci, 2007) (Allen et al., 2009) (Gomiscek et al., 2004) (Rao et al., 2009) affects amount of pollutants in a particular area. Many countries along with India set air quality monitoring programs to judge air quality (Bishnoi et al., 2009). For proper management of environment issues (Suess, 1979) (Titta et al., 2002) knowledge of air pollutants, concentrations, variations and field data are necessary, otherwise may affect planning. EPA initiated Air Quality Index (AQI) which gives quality of air based on rating scale (Ott and Jr. Hunt, 1976) (Ott and Thom, 1976) (USEPA, 2014) (Ontario, 2013). In Bikaner city, India higher particulate matter found during winters than monsoon (Charan and Sahel, 2014). $\mathrm{PM}_{10}$ was a key pollutant in moderately polluted Vapi city in India (Sarella and Khanbete, 2015). 72 AAQM stations compiled data for 2013-14 showed moderate to below quality of air (AQSM, 2013-2014). In continuation of earlier work (Aher et al., 2014) (Aher et al., 2014) (Dobhal et al., 2016) the current paper realizes air quality of residential (IMA hall) and industrial
(Krishidhan Seeds) sites of Jalna city from January to December 2016 using AQI.

\section{MATERIALS AND METHODS}

\section{Study Area}

Jalna district is in central part of Maharashtra state and on northern direction of Marathwada region, India with north latitudes $19^{\circ} 1^{1}$ to $23^{\circ} 3^{1}$ and $75^{\circ} 4^{1}$ to $76^{\circ} 4^{1}$ east longitudes, having an area of $7612 \mathrm{~km}^{2}$. District has subtropical climate with bulk rainfall of 650$750 \mathrm{~mm}$ from southwest monsoon between June to September. During drought rainfall reduces to 400 to 450 $\mathrm{mm}$. After monsoon in winter minimum temperature falls to $9^{\circ}-10^{\circ} \mathrm{C}$ and maximum goes to $30-35^{\circ} \mathrm{C}$. In summer maximum day temperature reaches to $42-45^{\circ} \mathrm{C}$ (Rajajoseph et al., 2014) (Erika et al., 2015).

Industrially Jalna is famous for Seeds, Steel along with other areas Engineering, Plastic and Agriculture. City is having six industrial areas under MIDC having industries of pulses, oil mills, refineries, steel re-rolling, plastics, tiles, cement pipes, fertilizers, insecticides, pesticides and the co-operative sugar factories. These industries along with automobiles are the key air polluting factors in the city (Harison and Yin, 2000) (UNCSD, 2001).

\section{Sampling and Analysis of Particulate Pollutant (RSPM and NRSPM)}

Twice a week during January to December 2016 RSPM, NRSPM, $\mathrm{SO}_{2}$ and NOx samples were collected from both sites using High volume air sampler (model RDS APM 460NL) with attachment APM 411TE (Enviro-tech make) can work for 24 hours. For RSPM

${ }^{1}$ Corresponding author 
and NRSPM air flow rate 1.1 to $1.2 \mathrm{~m}^{3} / \mathrm{min}$ for 8 hours maintained. The cyclone separator collects bigger particles NRSPM $>10 \mu \mathrm{m}$ size on previously weighed dust collector in first stage, RSPM (size $<10 \mu \mathrm{m})$ were collected on Whatmann GF/A glass microfiber filter. Using CPCB, 2011 gravimetrically the concentration of RSPM and NRSPM were found.

\section{Gaseous Pollutants ( $\mathrm{SO}_{2}$ and NOx)}

$\mathrm{SO}_{2}$ air samples were absorbed in absorbent solution of potassium tetrachloromercurate (TCM), complex formed dichlorosulphitomercurate was made to react with para rosaniline and methyl sulphonic acid. Spectrophotometer measurs absorbance at $530 \mathrm{~nm}$ of formed sulphate ions concentration in absorbent using West and Gaeke Method (IS 5182 part 2:2001); CPCB 2001.

Nitrogen dioxide from air bubbled through a solution of sodium hydroxide and sodium arsenite. Nitrile ion produced was treated with phosphoric acid, sulphanilamide and N-(1-naphthyl)-ethylenediamine dihydrochloride (NEDA) and measuring the absorbance of the highly coloured azo-dye at 540nm (Jacob and Hochheiser, 1958) (IS 5182-2, 2001).

\section{Air Quality Index (AQI)}

AQI is a single number showing actual concentration of criteria pollutants compared to its standard permissible values (Bortnick et al., 2002) (Murena, 2004). AQI guides in analyzing and representing uniform air quality status.

AQI Equation is

$$
A Q I=\left(\frac{100}{n}\right) \sum_{k=1}^{n}\left(\frac{A P C_{k}}{S P C_{k}}\right)
$$

Where, AQI= Air Quality Index

$\mathrm{n}=$ number of criteria pollutants

$\mathrm{APC}=$ Actual Pollutant Concentration

$\mathrm{SPC}=$ Standard Pollutant Concentration (CPCB, 2011)

Table 1: Indian National Ambient Air quality standard

\begin{tabular}{|c|c|c|c|c|}
\hline \multirow{2}{*}{$\begin{array}{l}\text { Sr. } \\
\text { No. }\end{array}$} & \multirow[b]{2}{*}{ Pollutant } & \multirow{2}{*}{$\begin{array}{l}\text { Time weighted } \\
\text { Average }\end{array}$} & \multicolumn{2}{|c|}{ Air Quality Standard concentration in Ambient air } \\
\hline & & & $\begin{array}{l}\text { Industrial, residential, rural } \\
\text { and other area }\end{array}$ & $\begin{array}{c}\text { Ecologically sensitive area (notified } \\
\text { by central Govt.) }\end{array}$ \\
\hline \multirow{2}{*}{1} & \multirow{2}{*}{$\mathrm{SO}_{2} \mu \mathrm{gm} / \mathrm{m}^{3}$} & Annual & 50 & 20 \\
\hline & & 24 hours & 80 & 80 \\
\hline \multirow{2}{*}{2} & $\mathrm{NO}_{2}$ & Annual & 40 & 30 \\
\hline & $\mu \mathrm{gm} / \mathrm{m}^{3}$ & 24 hours & 80 & 80 \\
\hline \multirow{2}{*}{3} & $\mathrm{PM}_{10}$ & Annual & 60 & 60 \\
\hline & $\mu \mathrm{gm} / \mathrm{m}^{3}$ & 24 hours & 100 & 100 \\
\hline \multirow{2}{*}{4} & $\mathrm{PM}_{2.5}$ & Annual & 40 & 40 \\
\hline & $\mu \mathrm{gm} / \mathrm{m}^{3}$ & 24 hours & 60 & 60 \\
\hline
\end{tabular}

AQI rating scale of is as shown below.

Table 2: Rating Scale of Air Quality Index (AQI) values

\begin{tabular}{|c|c|}
\hline AQI value & AQI Category \\
\hline $0-50$ & Good \\
\hline $51-100$ & Satisfactory \\
\hline $101-200$ & Moderately polluted \\
\hline $201-300$ & Poor \\
\hline $301-400$ & Very poor \\
\hline$>401$ & Severe \\
\hline
\end{tabular}

\section{RESULTS AND DISCUSSION}

The concentrations of $\mathrm{SO}_{2}, \mathrm{NOx}, \mathrm{RSPM}$ and NRSPM monitored at residential and industrial sites have been presented in table 3 and table 4 . 
Table 3: Monthly minimum, maximum and average concentration of $\mathrm{SO}_{2}$, NOx, RSPM and SPM $\left(\mu \mathrm{gm} / \mathrm{m}^{3}\right)$ at residential site

\begin{tabular}{|c|c|c|c|c|c|c|c|c|c|c|c|c|}
\hline \multirow[t]{2}{*}{ Month } & \multicolumn{3}{|c|}{$\begin{array}{c}\mathrm{SO}_{2}\left(\mu \mathrm{g} / \mathrm{m}^{3}\right) \text { Prescribed } \\
\quad \text { limit } 80 \mu \mathrm{g} / \mathrm{m}^{3}\end{array}$} & \multicolumn{3}{|c|}{$\begin{array}{c}\text { NOx }\left(\mu \mathrm{g} / \mathrm{m}^{3}\right) \\
\text { Prescribed limit } 80 \\
\mu \mathrm{g} / \mathrm{m}^{3}\end{array}$} & \multicolumn{3}{|c|}{$\begin{array}{c}\operatorname{RSPM}\left(\mu \mathrm{g} / \mathrm{m}^{3}\right) \text { Prescribed } \\
\operatorname{limit} 100 \mu \mathrm{g} / \mathrm{m}^{3}\end{array}$} & \multicolumn{3}{|c|}{$\begin{array}{c}\text { SPM }\left(\mu \mathrm{g} / \mathrm{m}^{3}\right) \text { Prescribed } \\
\text { limit } 200 \mu \mathrm{g} / \mathrm{m}^{3}\end{array}$} \\
\hline & Min. & Max. & Avg. & Min. & Max. & Avg. & Min. & Max. & Avg. & Min. & Max. & Avg. \\
\hline Jan & 9.75 & 15.95 & 12.63 & 27.89 & 30.21 & 29.36 & 87.00 & 175.00 & 128.00 & 370.00 & 507.00 & 449.00 \\
\hline Feb & 10.41 & 13.02 & 12.24 & 27.48 & 31.84 & 30.00 & 99.00 & 175.00 & 124.00 & 355.00 & 581.00 & 503.00 \\
\hline Mar & 8.17 & 15.47 & 11.58 & 23.57 & 30.23 & 27.84 & 104.00 & 159.00 & 122.00 & 398.00 & 618.00 & 489.00 \\
\hline Apr & 10.05 & 16.69 & 12.32 & 26.85 & 32.37 & 28.47 & 108.00 & 144.00 & 128.00 & 394.00 & 567.00 & 478.00 \\
\hline May & 11.48 & 16.54 & 13.35 & 29.62 & 34.77 & 31.81 & 101.00 & 147.00 & 128.00 & 328.00 & 476.00 & 411.00 \\
\hline June & 6.43 & 11.24 & 9.00 & 18.59 & 34.16 & 27.19 & 76.00 & 130.00 & 110.00 & 204.00 & 456.00 & 368.00 \\
\hline July & 9.72 & 15.06 & 11.96 & 25.98 & 41.48 & 29.43 & 75.00 & 131.00 & 98.00 & 186.00 & 449.00 & 305.00 \\
\hline Aug & 9.32 & 15.05 & 11.80 & 23.63 & 29.87 & 27.20 & 74.00 & 110.00 & 97.56 & 265.00 & 457.00 & 366.00 \\
\hline Sept & 9.70 & 13.51 & 11.38 & 22.32 & 31.95 & 28.17 & 48.00 & 113.00 & 84.00 & 130.00 & 339.00 & 237.00 \\
\hline Oct & 3.26 & 5.21 & 4.27 & 15.94 & 43.49 & 30.81 & 109.00 & 130.00 & 118.00 & 291.00 & 605.00 & 478.00 \\
\hline Nov & 3.92 & 6.20 & 5.16 & 23.20 & 36.53 & 30.69 & 116.00 & 362.00 & 208.00 & 405.00 & 897.00 & 720.00 \\
\hline Dec & 11.51 & 15.15 & 13.84 & 28.97 & 39.94 & 35.72 & 158.00 & 248.00 & 188.00 & 544.00 & 871.00 & 749.00 \\
\hline Average & 8.64 & 13.25 & 10.79 & 25.79 & 33.44 & 29.72 & 96.25 & 168.66 & 127.79 & 322.50 & 568.58 & 462.75 \\
\hline
\end{tabular}

Table 4: Monthly minimum, maximum and average concentration of $\mathrm{SO}_{2}$, NOx, RSPM and SPM $\left(\mu \mathrm{gm} / \mathrm{m}^{3}\right)$ at industrial site

\begin{tabular}{|c|c|c|c|c|c|c|c|c|c|c|c|c|}
\hline \multirow[t]{2}{*}{ Month } & \multicolumn{3}{|c|}{$\begin{array}{c}\mathrm{SO}_{2}\left(\mu \mathrm{g} / \mathrm{m}^{3}\right) \text { Prescribed } \\
\text { limit } 80 \mu \mathrm{g} / \mathrm{m}^{3}\end{array}$} & \multicolumn{3}{|c|}{$\begin{array}{c}\text { NOx }\left(\mu \mathrm{g} / \mathrm{m}^{3}\right) \\
\text { Prescribed limit } 80 \\
\mu \mathrm{g} / \mathrm{m}^{3}\end{array}$} & \multicolumn{3}{|c|}{$\begin{array}{c}\text { RSPM }\left(\mu \mathrm{g} / \mathrm{m}^{3}\right) \\
\text { Prescribed limit } 100 \\
\mu \mathrm{g} / \mathrm{m}^{3}\end{array}$} & \multicolumn{3}{|c|}{$\begin{array}{c}\text { SPM }\left(\mu \mathrm{g} / \mathrm{m}^{3}\right) \text { Prescribed } \\
\text { limit } 200 \mu \mathrm{g} / \mathrm{m}^{3}\end{array}$} \\
\hline & Min. & Max. & Avg. & Min. & Max. & Avg. & Min. & Max. & Avg. & Min. & Max. & Avg. \\
\hline Jan & 9.73 & 15.74 & 11.71 & 28.70 & 34.34 & 31.62 & 87.00 & 97.00 & 93.00 & 166.00 & 344.00 & 227.00 \\
\hline Feb & 11.07 & 13.43 & 11.93 & 27.09 & 31.16 & 29.41 & 91.00 & 101.00 & 94.00 & 213.00 & 248.00 & 232.00 \\
\hline Mar & 11.68 & 14.59 & 13.52 & 28.75 & 36.61 & 13.52 & 89.00 & 98.00 & 95.00 & 203.00 & 297.00 & 241.00 \\
\hline Apr & 12.31 & 14.72 & 13.44 & 28.74 & 38.21 & 32.81 & 84.00 & 96.00 & 92.00 & 244.00 & 503.00 & 374.00 \\
\hline May & 9.83 & 13.39 & 11.49 & 29.35 & 34.41 & 31.24 & 77.00 & 96.00 & 89.00 & 267.00 & 434.00 & 356.00 \\
\hline June & 6.31 & 13.34 & 9.25 & 24.35 & 29.56 & 26.61 & 68.00 & 93.00 & 82.00 & 189.00 & 413.00 & 288.00 \\
\hline July & 9.73 & 16.32 & 12.63 & 23.80 & 35.57 & 27.48 & 72.00 & 96.00 & 89.00 & 157.00 & 253.00 & 200.00 \\
\hline Aug & 10.25 & 14.00 & 12.06 & 23.08 & 31.99 & 28.62 & 65.00 & 95.00 & 83.00 & 236.00 & 333.00 & 275.00 \\
\hline Sept & 9.25 & 14.06 & 11.70 & 22.32 & 33.67 & 27.66 & 67.00 & 96.00 & 78.00 & 197.00 & 341.00 & 258.00 \\
\hline Oct & 11.78 & 13.76 & 12.91 & 28.48 & 31.68 & 30.81 & 81.00 & 95.00 & 91.00 & 200.00 & 363.00 & 289.00 \\
\hline Nov & 5.47 & 10.24 & 8.37 & 32.98 & 41.94 & 37.24 & 74.00 & 96.00 & 87.00 & 117.00 & 186.00 & 164.00 \\
\hline$\overline{\text { Dec }}$ & 11.99 & 15.52 & 13.70 & 26.64 & 44.57 & 35.53 & 82.00 & 94.00 & 89.00 & 168.00 & 227.00 & 200.00 \\
\hline Average & 9.95 & 14.09 & 11.89 & 27.02 & 35.30 & 29.37 & 78.08 & 96.08 & 88.50 & 196.41 & 328.50 & 258.66 \\
\hline
\end{tabular}

\section{Sulphur Dioxide $\left(\mathrm{SO}_{2}\right)$}

The monthly minimum, maximum, and average concentrations at residential site were varied between $3.26-11.51 \mu \mathrm{g} / \mathrm{m}^{3}, \quad 5.21-16.69 \mu \mathrm{g} / \mathrm{m}^{3}$ and $4.27-13.84$ $\mu \mathrm{g} / \mathrm{m}^{3}$ respectively. The highest concentration of $\mathrm{SO}_{2}$ $\left(16.69 \mu \mathrm{g} / \mathrm{m}^{3}\right)$ at residential site was recorded in the month of April followed by May $\left(16.54 \mu \mathrm{g} / \mathrm{m}^{3}\right)$. The lowest concentration of $\mathrm{SO}_{2}\left(3.26 \mu \mathrm{g} / \mathrm{m}^{3}\right)$ was observed in month October at residential site. The monthly minimum, maximum and average concentrations at industrial sites were varied between $5.47-12.31 \mu \mathrm{g} / \mathrm{m}^{3}$, $10.24-16.32 \mu \mathrm{g} / \mathrm{m}^{3}$ and $8.37-13.70 \mu \mathrm{g} / \mathrm{m}^{3}$ respectively. The industrial site generally recorded the higher concentrations of $\mathrm{SO}_{2}$ compared to the residential site. The $\mathrm{SO}_{2}$ concentration at industrial site was observed highest $\left(16.32 \mu \mathrm{g} / \mathrm{m}^{3}\right)$ in the month of July followed by $\left(15.74 \mu \mathrm{g} / \mathrm{m}^{3}\right)$ in January while $5.47 \mu \mathrm{g} / \mathrm{m}^{3}$ was reported 
DOBHAL ET AL.: AMBIENT AIR QUALITY ASSESSMENT OF JALNA CITY (MS), INDIA

lowest in month of November. Monthly mean variation of $\mathrm{SO}_{2}$ at both sites is as shown in Graph-1.
The seasonal trend in concentration of $\mathrm{SO}_{2}$ was as shown in table 5.

Table 5: Seasonal Minimum, Maximum and Average concentration of pollutants $\left(\mu \mathrm{gm} / \mathrm{m}^{3}\right)$ at residential and industrial sites

\begin{tabular}{|c|c|c|c|c|c|c|c|}
\hline \multirow{2}{*}{ Season } & \multirow{2}{*}{ Pollutant } & \multicolumn{3}{|c|}{ Residential } & \multicolumn{3}{|c|}{ Industrial } \\
\hline & & Min. & Max. & Avg. & Min. & Max. & Avg. \\
\hline \multirow{5}{*}{ Summer } & $\mathrm{SO}_{2}$ & 8.17 & 16.69 & 12.37 & 9.83 & 14.72 & 12.60 \\
\hline & NOx & 23.57 & 34.77 & 29.53 & 27.09 & 38.21 & 26.75 \\
\hline & RSPM & 99.00 & 175.00 & 125.50 & 77.00 & 101.00 & 92.50 \\
\hline & SPM & 328.00 & 618.00 & 470.25 & 203.00 & 503.00 & 300.75 \\
\hline & $\mathrm{AQI}$ & \multicolumn{3}{|r|}{125.50} & \multicolumn{3}{|r|}{92.50} \\
\hline \multirow{5}{*}{ Monsoon } & $\mathrm{SO}_{2}$ & 6.43 & 15.06 & 11.04 & 6.31 & 16.32 & 11.41 \\
\hline & NOx & 18.59 & 34.16 & 28.00 & 22.32 & 35.57 & 27.59 \\
\hline & RSPM & 48.00 & 131.00 & 97.39 & 65.00 & 96.00 & 83.00 \\
\hline & SPM & 130.00 & 457.00 & 319.00 & 157.00 & 413.00 & 255.25 \\
\hline & AQI & \multicolumn{3}{|r|}{97.39} & \multicolumn{3}{|r|}{83.00} \\
\hline \multirow{5}{*}{ Winter } & $\mathrm{SO}_{2}$ & 3.26 & 15.95 & 8.98 & 5.47 & 15.74 & 11.67 \\
\hline & NOx & 15.94 & 43.49 & 31.65 & 26.64 & 44.57 & 33.80 \\
\hline & RSPM & 87.00 & 362.00 & 160.50 & 74.00 & 97.00 & 90.00 \\
\hline & SPM & 291.00 & 897.00 & 599.00 & 117.00 & 363.00 & 220.00 \\
\hline & AQI & \multicolumn{3}{|r|}{160.50} & & & 90.00 \\
\hline
\end{tabular}

The highest seasonal concentration of $\mathrm{SO}_{2}$ at residential site was observed in summer $\left(16.69 \mu \mathrm{g} / \mathrm{m}^{3}\right)$ followed by winter $\left(15.95 \mu \mathrm{g} / \mathrm{m}^{3}\right)$. The least concentration of $\mathrm{SO}_{2}$ at residential site was observed in winter season $\left(3.26 \mu \mathrm{g} / \mathrm{m}^{3}\right)$. Industrial site recorded highest concentration of $\mathrm{SO}_{2}$ in monsoon $\left(16.32 \mu \mathrm{g} / \mathrm{m}^{3}\right)$ followed by winter $\left(15.74 \mu \mathrm{g} / \mathrm{m}^{3}\right)$ and lowest was reported in winter season $\left(5.47 \mu \mathrm{g} / \mathrm{m}^{3}\right)$. Seasonal mean variation of $\mathrm{SO}_{2}$ is as shown in Graph 5.

The annual mean minimum, maximum and average concentration of $\mathrm{SO}_{2}$ at residential site obtained was $8.64 \mu \mathrm{g} / \mathrm{m}^{3}, \quad 13.25 \mu \mathrm{g} / \mathrm{m}^{3}$ and $10.79 \mu \mathrm{g} / \mathrm{m}^{3}$ respectively. While the annual mean minimum, maximum and average concentration of $\mathrm{SO}_{2}$ at industrial site obtained were $9.95 \mu \mathrm{g} / \mathrm{m}^{3}, 14.09 \mu \mathrm{g} / \mathrm{m}^{3}$ and $11.89 \mu \mathrm{g} / \mathrm{m}^{3}$ respectively, which were well below the national ambient air quality standards (NAAQS) specified by the central pollution control board (CPCB, 2009).

\section{Oxides of Nitrogen (NOx)}

The monthly minimum, maximum and average concentrations of oxides of nitrogen ( $\mathrm{NOx}$ ) at residential site were ranged from $15.94-29.62 \mu \mathrm{g} / \mathrm{m}^{3}, 25.98-43.49$ $\mu \mathrm{g} / \mathrm{m}^{3}$ and $27.19-35.72 \mu \mathrm{g} / \mathrm{m}^{3}$ respectively. The highest monthly concentration was reported in October (43.49 $\left.\mu \mathrm{g} / \mathrm{m}^{3}\right)$ followed by July $\left(41.48 \mu \mathrm{g} / \mathrm{m}^{3}\right)$. While 15.94 $\mu \mathrm{g} / \mathrm{m}^{3}$ being lowest reported in the October. Thus highest and lowest concentrations of NOx at residential site were recorded in October. The monthly minimum, maximum and average concentrations of oxides of nitrogen (NOx) at industrial site were varied from 22.32-32.98 $\mu \mathrm{g} / \mathrm{m}^{3}$, $29.56-44.57 \mu \mathrm{g} / \mathrm{m}^{3}$ and $13.52-37.24 \mu \mathrm{g} / \mathrm{m}^{3}$ respectively. The highest monthly concentration was reported in December $\left(44.57 \mu \mathrm{g} / \mathrm{m}^{3}\right)$ followed by November (41.94 $\left.\mu \mathrm{g} / \mathrm{m}^{3}\right)$. While $22.32 \mu \mathrm{g} / \mathrm{m}^{3}$ being lowest reported in the September. Monthly mean variation of NOx is as shown in Graph 2.

Seasonally the highest mean concentration of NOx was observed during winter $\left(43.49 \mu \mathrm{g} / \mathrm{m}^{3}\right)$ at residential site and again in winter $\left(44.57 \mu \mathrm{g} / \mathrm{m}^{3}\right)$ at industrial site. The lowest concentration of $\mathrm{NOx}$ at residential site was observed during winter $\left(15.94 \mu \mathrm{g} / \mathrm{m}^{3}\right)$ while at industrial site it was recorded $\left(22.32 \mu \mathrm{g} / \mathrm{m}^{3}\right)$ during monsoon. The annual mean concentration of $\mathrm{NOx}$ at residential and industrial site was recorded $29.72 \mu \mathrm{g} / \mathrm{m}^{3}$ and $29.37 \mu \mathrm{g} / \mathrm{m}^{3}$ respectively which were below the NAAQS (CPCB 2009). Seasonal mean concentration variation of NOx is as shown in Graph 6.

The major contributors of Sulphur dioxide $\left(\mathrm{SO}_{2}\right)$ and oxides of nitrogen (NOx) to ambient air are automobiles and industries (Muschate and Chougale, 
2011). The seasonal concentration pattern of air pollutants is driven by emission characteristics of the dominant sources and meteorological conditions (Gomiscek et al., 2004), similar results reported by other scholars (Bhanarkar et al., 2002) (Kaushik et al., 2006).

\section{Particulate Pollutants}

The monthly minimum, maximum and average concentration of RSPM and NRSPM observed at residential and industrial site has been reported in table no. $3 \& 4$

\section{Respirable Suspended Particulate Matter RSPM ( $\leq$ $\mathbf{P M}_{10}$ )}

The annual mean concentration of RSPM ( $\leq$ $\left.\mathrm{PM}_{10}\right)$ at residential site was found $127.79 \mu \mathrm{g} / \mathrm{m}^{3}$, beyond the maximum permissible limits of NAAQS (Table 1). November recorded highest monthly mean RSPM concentration $362 \mu \mathrm{g} / \mathrm{m}^{3}$ and the lowest $48 \mu \mathrm{g} / \mathrm{m}^{3}$ in September. Seasonally winter recorded highest levels of RSPM $362 \mu \mathrm{g} / \mathrm{m}^{3}$ at residential site and at industrial site $101 \mu \mathrm{g} / \mathrm{m}^{3}$. RSPM monthly mean concentration varied from $84-208 \mu \mathrm{g} / \mathrm{m}^{3}$ at residential site and at industrial site it varied from $78-95 \mu \mathrm{g} / \mathrm{m}^{3}$ as shown in Graph 3. The annual mean RSPM reported at industrial site was 88.5 $\mu \mathrm{g} / \mathrm{m}^{3}$ which is below the existing NAAQS. Seasonal mean variation of RSPM is as shown in Graph 7.

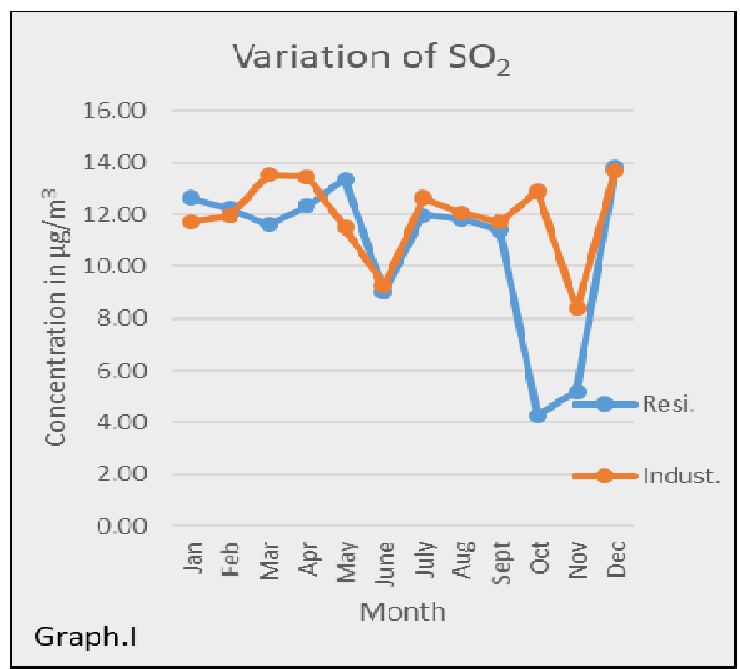

Graph 1: Monthly variation of Concentration of $\mathrm{SO}_{2}$

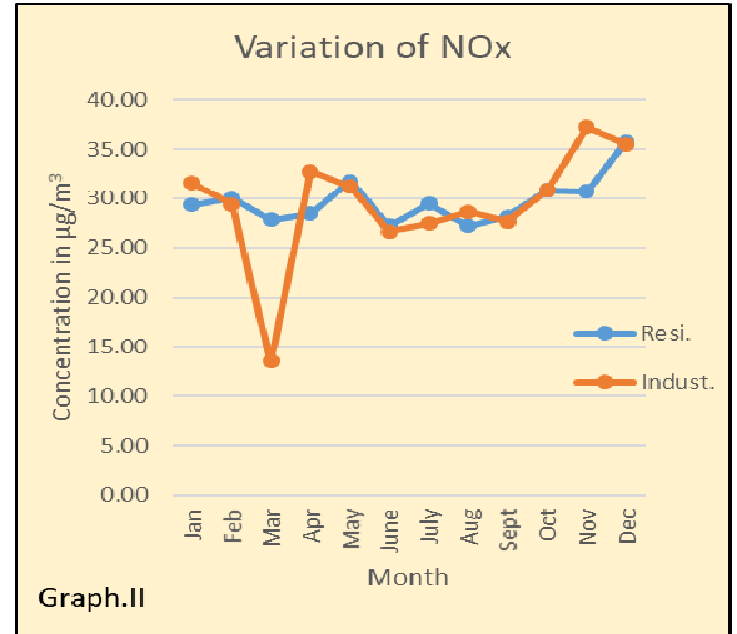

Graph 2: Monthly variation of Concentration of NOx

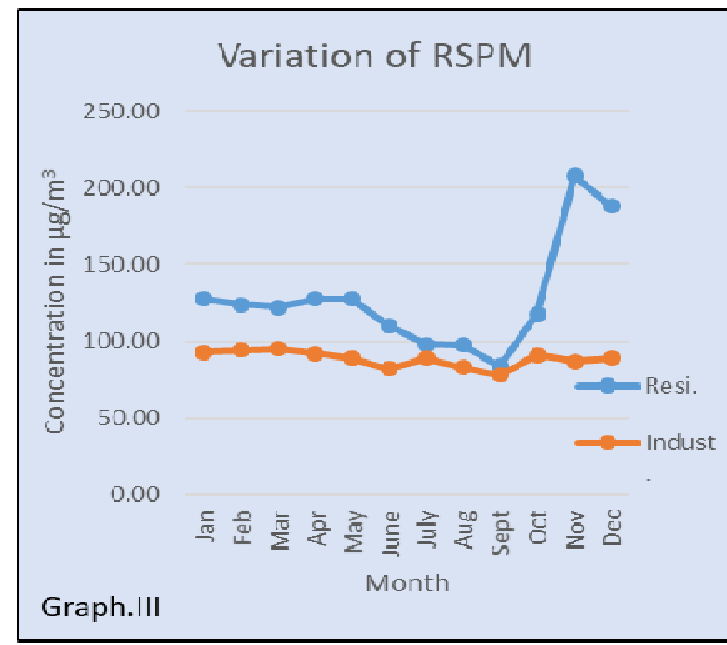

Graph 3: Monthly variation of Concentration of RSPM

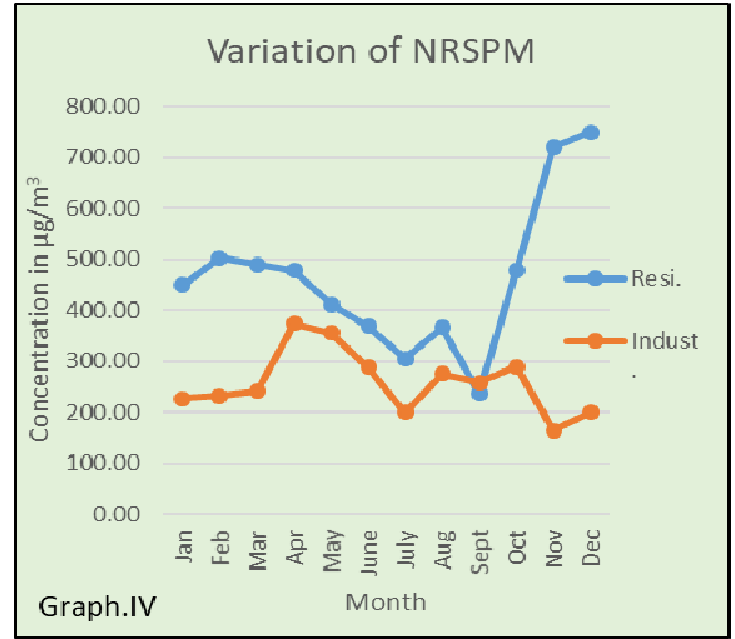

Graph 4: Monthly variation of Concentration of NRSPM 
DOBHAL ET AL.: AMBIENT AIR QUALITY ASSESSMENT OF JALNA CITY (MS), INDIA

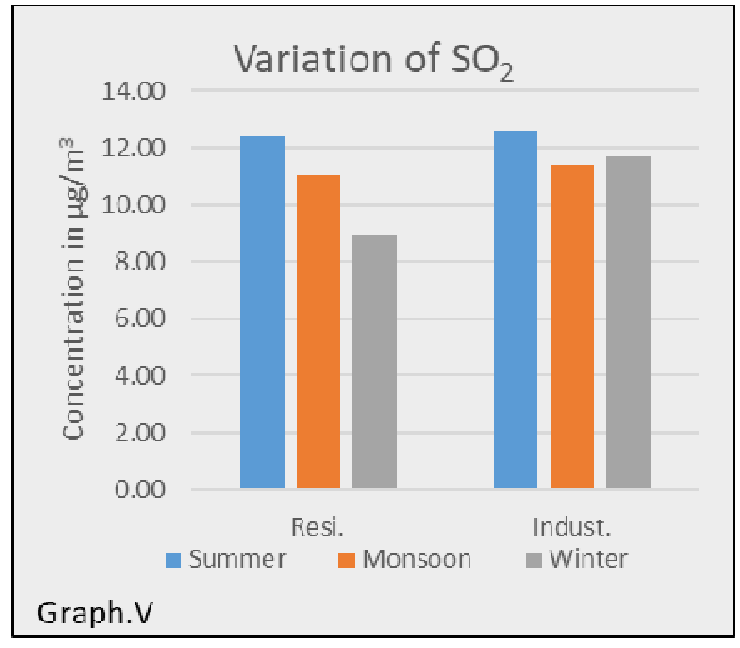

Graph 5: Seasonal variation of Concentration of $\mathrm{SO}_{2}$

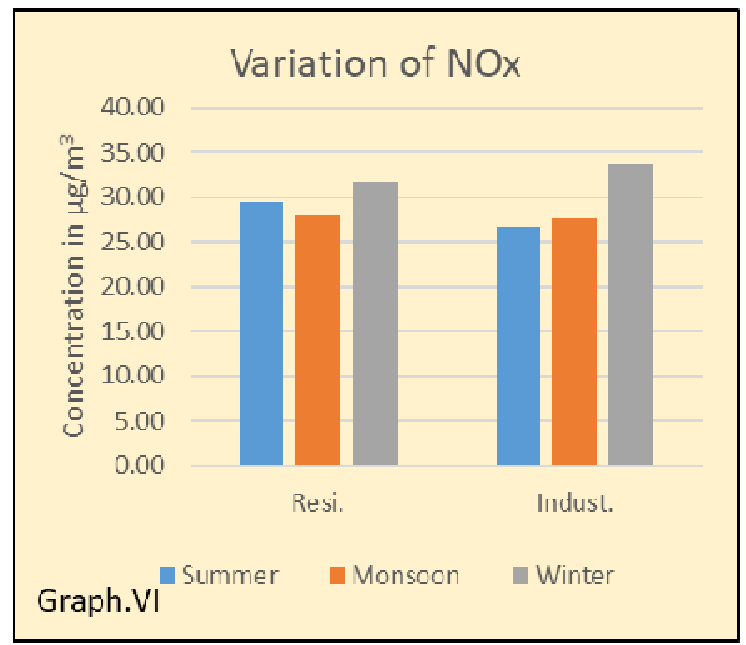

Graph 6: Seasonal variation of Concentration of NOx

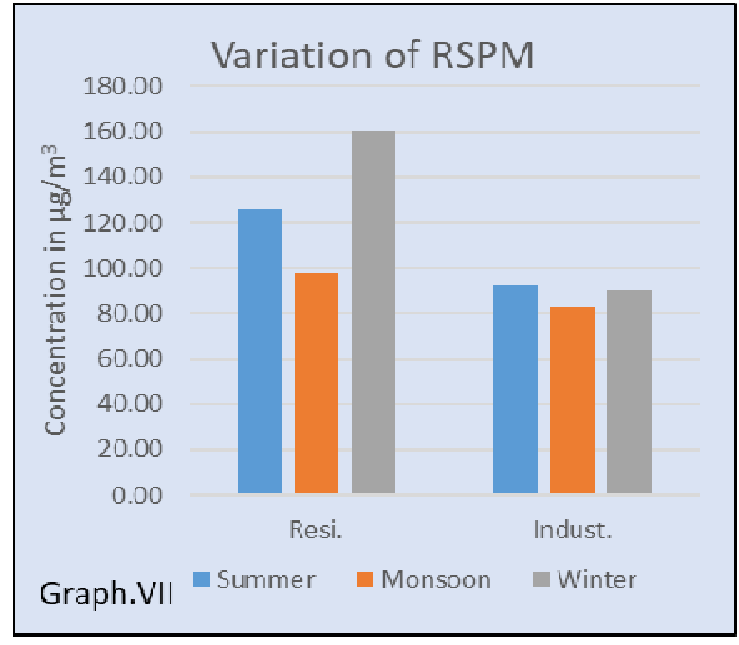

Graph 7: Seasonal variation of Concentration of RSPM

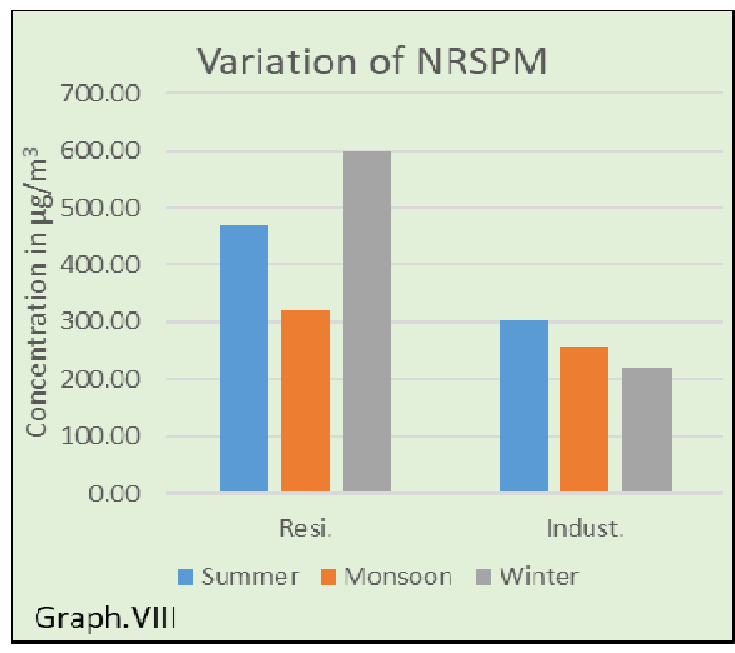

Graph 8: Seasonal variation of Concentration of NRSPM

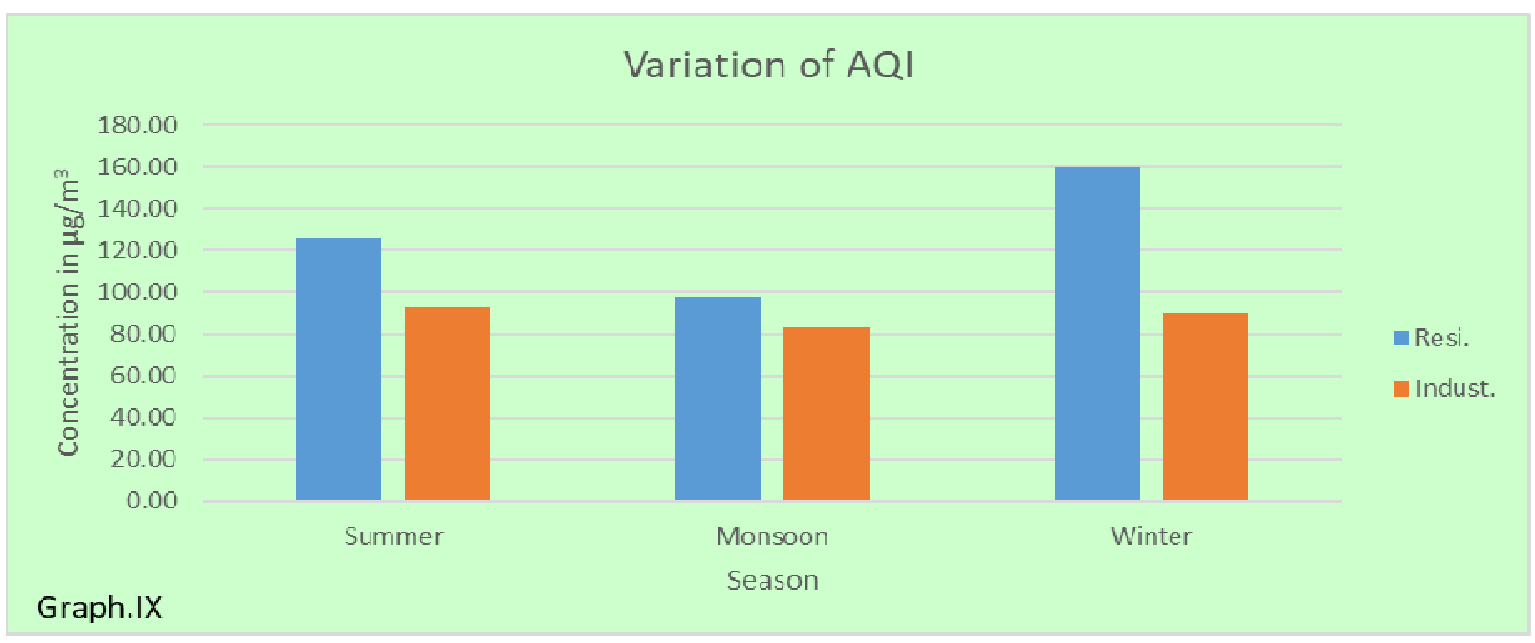

Graph 9: Seasonal variation of AQI 


\section{Non Respirable Suspended Particulate Matter (NRSPM) $\geq$ PM $_{10}$}

NRSPM monthly mean concentration was ranged between $237-749 \mu \mathrm{g} / \mathrm{m}^{3}$ and $164-374 \mu \mathrm{g} / \mathrm{m}^{3}$ and annual mean concentration were recorded $462.75 \mu \mathrm{g} / \mathrm{m}^{3}$ and $258.66 \mu \mathrm{g} / \mathrm{m}^{3}$ at residential and industrial site respectively. NRSPM highest monthly mean concentration at residential site was found $749 \mu \mathrm{g} / \mathrm{m}^{3}$ in December followed by $720 \mu \mathrm{g} / \mathrm{m}^{3}$ in November. At industrial site highest NRSPM concentration $503 \mu \mathrm{g} / \mathrm{m}^{3}$ was in April followed by $434 \mu \mathrm{g} / \mathrm{m}^{3}$ in May. Lowest NRSPM at residential site was recorded in September 130 $\mu \mathrm{g} / \mathrm{m}^{3}$ as shown in Graph 4.

Seasonal NRSPM concentrations varied significantly at both the monitoring sites. The highest mean NRSPM levels were recorded in winter as 749 $\mu \mathrm{g} / \mathrm{m}^{3}$ followed by $720 \mu \mathrm{g} / \mathrm{m}^{3}$ again in winter at residential site. While highest mean NRSPM levels were recorded in summer $374 \mu \mathrm{g} / \mathrm{m}^{3}$ followed by $356 \mu \mathrm{g} / \mathrm{m}^{3}$ again in summer at industrial site. Lowest NRSPM concentration for residential site was recorded in monsoon as $237 \mu \mathrm{g} / \mathrm{m}^{3}$ and $164 \mu \mathrm{g} / \mathrm{m}^{3}$ for industrial site during winter. Seasonal mean variation of NRSPM is as shown in Graph 8. The major contributors of particulate pollutants in ambient air are automobiles and industries (Hrdlickova et al., 2008). The seasonal variation pattern of RSPM and NRSPM concentration can be seen from the values presented in table. $\mathrm{V}$. The variation pattern is caused by the meteorological effects i.e. vertical mixing in summer and frequent inversions in winter (Gomiscek et al., 2004). The pattern for urban sites are basically similar for both summer and winter suggesting that most important emission sources are seasonally independent for urban areas and are surely traffic emissions and industries. Seasonal mean variation of AQI is as shown in Graph 9. AQI values for residential site obtained are between 101 and 200 due to higher particulate matter indicate moderate pollution as per the rating scale (table 2). Members of sensitive groups like older adults and children may experience health effects like heart or lung disease on prolong exposure and at greater risk compared to general public. While AQI values for industrial site obtained are between 51 and 100 due to higher particulate matter indicate satisfactory level of pollution as per the rating scale (table 2), which will have less effect even on sensitive group of persons.

\section{CONCLUSION}

Analysis of variations of $\mathrm{SO}_{2}, \mathrm{NOx}, \mathrm{RSPM}$ and NRSPM based on one-year study at Jalna city arearesidential and industrial site shown that the particulate pollutants at both sites were found to be higher due to wind flow and location. The annual mean gaseous pollutants measured at residential site were found within the permissible limits of NAAQS, whereas RSPM concentrations violated the prescribed limit more at residential and less at industrial site. Whereas NRSPM concentrations violated the prescribed limit at both sites. The seasonal cycle for $\mathrm{SO}_{2}$ at both sites showed higher concentration during summer and lower in monsoon. The NOx, RSPM and NRSPM concentration was found to be higher in winter and lower in monsoon at both sites, only NRSPM concentration higher in summer at industrial site. Ambient air quality was found to be better in monsoon season.

\section{ACKNOWLEDGEMENT}

Authors are thankful to Director, Maharashtra pollution control board (MPCB), Aurangabad, Badrinarayan Barwale College, Jalna and Enviro-tech lab for their supports like financial, technical, scientific, laboratory, infrastructure, co-operation, guidance and suggestion, also to everyone who helped directly or indirectly for work.

\section{REFERENCES}

Atash F., 2007. The determination of urban environments in developing countries: Mitigating the air pollution crises in Tehran, Iran cities, 24(6): 399-409.

Allen R.W., Davies H., Cohen M.A., Mallach G., Kaufman J.D. and Adar S.D., 2009. The spatial relationship between traffic generated air poll. and noise in 2 US cities, Env. Res., 109(3): 334342.

Air Quality Status of Maharashtra 2013-2014, Compilation of Air Quality data recorded by MPCB, 2014

Aher S.B., Dobhal B.S. and Awasthi R.S., 2014. Spatial and Temporal Variations of $\mathrm{SO}_{2}, \mathrm{NOx}, \mathrm{PM}_{10}$ and TSPM Concentration in Ambient Air of Jalna City, India, Int. J. of Agric., Env. \& Biotech., 7(3); 571-579.

Aher S.B., Dobhal B.S. and Awasthi R.S., 2014. Assessment of Ambient Air Quality of Jalna 


\section{DOBHAL ET AL.: AMBIENT AIR QUALITY ASSESSMENT OF JALNA CITY (MS), INDIA}

City, India using Air Quality Index, Indian J. of Env. Sci., 18(2): 65-72.

Bhanarkar A.D., Gajphate D.G. and Hasan M.Z., 2002. Air poll. concentration in Haryana sub-region, India, Bull. of Env. Contam. and Toxicology, 69: 690-695.

Bortnick S.M., Coutant B.W. and Eberly S.I., 2002. Using continuous $\mathrm{PM}_{2.5}$ monitoring data reports on Air Quality Index, J. of the Air and waste manage. Assoc., 52: 104-112.

Bishnoi B., Amit P. and Jain V.K., 2009. A comparative study of air qual. index on factor analysis and US. EPA methods for an urban Environment, Aerosol and Air Qual. Res., 9:1-17.

Baladauf R.W., Watkinns N., Heist D., Bailey C., Rowley P. and Shores R., 2009. Near air quality monitoring factors affecting network design and interpretation of data, Air Quality Atmos. and Health, 2: 1-9.

Celis J.E., Morales J.R., Zaror C.A. and Inzunza J.C., 2004. A study of particulate matter $\mathrm{PM}_{10}$ composition in the atmosphere of Chile, Atmos. 54(5): 541-550.

Charan P.D. and Sahel H., 2014, Study of respirable dust in Ambient Air of Bikaner city and its impact on human health, Appl. J. of Hygiene, 3: 11-14.

CPCB (Central Poll. Cont. Board), 2011. Guidelines for the measurements of Ambient Air Poll. in New Delhi, India (1):55.

CPCB (Central Poll. Cont. Board), 2009. Indian National Ambient Air Quality Standards, New Delhi.

Dobhal B.S., Jadhav S., Sangvikar M. and Farooqui M., 2016. Study of Ambient Air Quality of Jalna City (MS), India, Ultra Chem., 12(2): 29-34.

Erika Von Schueidemesser, Paul S Monks, James D Allens, Lori Bruhwiler, Piers Forster, David Flower, Alex Lauer, William T Morgan, Pauli Passonen, Mattia Righi, Katerinasindelarova and Mark A Sutton, 2015. Chem. and linkage between air quality and climate change, Chem. Reviews, 115: 3856-3897.

Franchini M. and Mannucci P.M., 2007. Short term effects of air pollution on cardiovascular disease outcomes and mechanisms, J. of Thrombosis and Haemostasis, 5(11): 2169-2174.
Gupta A.K., Patil R.S. and Gupta S.K., 2003. A long term study of oxides of nitrogen, Env. Sci. and Health, 38: 2877-2894.

Gomiscek B., Stopper S., Preining O. and Hauck H., 2004. Spatial and temporal variations in $\mathrm{PM}_{1}$, $\mathrm{PM}_{2.5}, \mathrm{PM}_{10}$ and particle number concentration during AUPHEP project, Atmos. Env., 38: 39173934.

Harison R.M. and Yin J., 2000. Particulate matter in atmosphere; which particle properties are important for its effects on health, The Sci. of the total Env., 249: 85-101.

Harison R.M. and Yin J., 2000. Particulate matter in the Atmos.: which particle properties are important for its effects on health? The Sci. of the Total Env., 249: 85-101.

Hrdlickova Z., Michalek J., Kolar M. and Vesley V., 2008. Identification of factors affecting air poll. by dust aerosol $\mathrm{PM}_{10}$ in Brno city, Czeck Republic, Atmos. Env., 42(37): 8661-8673.

IS 5182.2, 2001, Methods for measurement of Air poll. part-2, Sulphur Dioxide (CHD 32: Env. Prot. and Waste measurement).

IS 5182-2, 2001, Methods for measurement of Air poll., Part 6: oxides of nitrogen (CHD 32: Env. Prot. and waste manage.)

Jacob M.B. and Hochheiser S., 1958. Continuous Sampling and ultra micro determinations of nitrogen dioxide in air, Analytical Chem., 30:426.

Kaushik C.P., Ravindra K., Yadav K., Mehta S. and Haritash A.K., 2006. Assessment of ambient Air Quality in urban centers of Haryana (India) in relation of different anthropogenic activities and health risks, Env. Monitoring and Asses., 122: 27-40.

Kim K.H., Lee J.H. and Jang M.S., 2002. Metals in Airborne particulate matter from first and second industrial complex area of Taejon City, Korea, Env. Poll., 118: 41-51.

Murena F., 2004. measuring air quality over large urban areas; Develop. and application of an air poll. Index at the urban areas of Neples, Atmos. Env., 38: 6195-6202. 


\section{DOBHAL ET AL.: AMBIENT AIR QUALITY ASSESSMENT OF JALNA CITY (MS), INDIA}

Muschate N.S. and Chougale A.M., 2011. Study of ambient concentration of air quality parameters $\left(\mathrm{PM}_{10}, \mathrm{SPM}, \mathrm{SO}_{2}\right.$ and $\left.\mathrm{NOx}\right)$ in different months, European J. of Experimental Biol., 1(1): 90-96.

Ott W.R. and Jr. Hunt W.F., 1976. A quantitative evaluation of the pollutant standard index, J. of Air Poll. Cont. Assoc., 26:1950-1954.

Ott W.R. and Thom G.C., 1976. A critical review of air pollution index systems in the United States and Canada, J. of Air Poll. Cont. Assoc., 26:460-470.

Ontario, 2013. Review of the Ontario air quality index and air quality health index system. Air resonance Branch, Ontario ministry of the Env., Toranto, Ontario, Canada.

Rajajoseph D., Mathan Y. and Rajivgandhi V., 2014. Efficient and Env. friendly NOx emission reduction design of Aero Engine gas turbine Combustor, IJEP, 34(8): 645-652.

Rao B.P.S., Mhaisalkar V.M., Kumar A., Shrivastava A. and Devotta S., 2009. Seasonal variations of Ambient levels of Sulphur dioxide in and around a typical Indian Petroleum Refinery, Int. J. of Earth Sci. and Eng., 2(3): 231-237.

Sarella G. and Khanbete A.K., 2015. Ambient Air Quality, Analysis using Air Quality Index. A case study of Vapi, India IJIRST, 1: 68-71.
Sharek M., Cupre P., Bartos T., Kohutek J., Klanova J. and Holoubek I., 2007. A combined approach to the evaluation of organic air poll. A case study of urban air in Sarajevo and Tuzla (Bosnia and Harzegovina), Sci. of the total Env., 384(13): 182-193.

Suess M.J., 1979. An Env. approach to air quality monitoring, Atmos. Env., 13:211-221.

Tashiro Y. and Taniyama T., 2002. Atmos. $\mathrm{NO}_{2}$ and $\mathrm{CO}$ concentration in Lima, Peru, Env. Int., 28: 227333.

Titta P., Raunemma T., Tissari J., Vli-Tuomi T., Leskinen A., Kukkonen J., Harkonen J. and Karppinen A., 2002. Measurements and modeling of $\mathrm{PM}_{2.5}$ concentrations near a major road in Kuopio, Finland, Atmos. Env., 36:4057-4068.

USEPA, 2014. United States Env. Prot. Agency.

UNCSD, 2001. Protection of the atmos.- Report to the secretary General, E/CN.17/2001/2, commission for sustainable Develop., New York, USA.

Zhang M., Song Y. and Cai X., 2007. A health based assessment of particulate air poll. in urban areas of Beijing in 2000-2004, Sci. of the Total Env., 378(13) 3: 100-108. 